\title{
Peroxisome proliferator-activated receptors in the regulation of female reproductive functions
}

\author{
Iwona Bogacka ${ }^{1}$, Aleksandra Kurzynska ${ }^{1}$, Marek Bogacki ${ }^{2}$, Katarzyna Chojnowska ${ }^{1}$ \\ ${ }^{1}$ Department of Animal Physiology, University of Warmia and Mazury in Olsztyn, Poland \\ ${ }^{2}$ Institute of Animal Reproduction and Food Research of Polish Academy of Sciences, Olsztyn, Poland
}

\begin{abstract}
Peroxisome proliferator-activated receptors (PPARs) belong to a ligand-dependent nuclear receptor family. In the past decade, numerous studies have revealed the presence and significance of PPARs in the reproductive system. PPARs are expressed at different levels of hypothalamic-pituitary-gonadal (HPG) axis. They are also present in the uterus as well as in the placenta and embryonic tissues of different species. PPARs significance has been reported during the estrous/menstrual cycle and pregnancy with the gamma isoform studied most frequently. Several studies indicate that PPARs regulate proliferation of ovarian cells, tissue remodeling and steroidogenesis. In the endometrium, PPARs are engaged in the regulation of prostaglandins, steroids and cytokines synthesis. The role of PPARs in the trophoblast differentiation, maturation and invasion as well as in the embryo development has also been demonstrated. In this review, we summarize current findings concerning the role of PPARs in the regulation of reproductive functions at different levels of the HPG axis during various physiological statuses of females. In addition, the role of PPARs in the modulation of uterine functions as well as the placenta and embryo development has also been discussed. (Folia Histochemica et Cytobiologica 2015, Vol. 53, No. 3, 189-200)
\end{abstract}

Key words: PPARs; ovary; uterus; placenta; reproduction; estrous cycle; pregnancy

\begin{abstract}
Abbreviations: $3 \beta$-HSD - 3- $\beta$-hydroxysteroid dehydrogenase $/ \Delta-5-4$ isomerase, $\mathrm{CL}$ - corpus luteum, CYP - cytochrome P450, $\mathrm{E}_{2}$ - estradiol, FSH follicle-stimulating hormone, HP axis - hypothalamic-pituitary axis, IL — interleukin, LH - luteinizing hormone, MMP - matrix metalloproteinase, NOS - nitric oxide synthase, $\mathrm{P}_{4}$ - progesterone, PCOS - polycystic ovary syndrome, $\mathrm{PG}$ - prostaglandin, PPAR - peroxisome proliferator-activated receptor, StAR - steroidogenic acute regulatory protein, TNF $\alpha$ - tumor necrosis factor alpha, TZD — thiazolidinediones, VEGF — vascular endothelial growth factor
\end{abstract}

Correspondence address: Assoc. Prof. I. Bogacka

Department of Animal Physiology

University of Warmia and Mazury

Oczapowskiego St. 1A, 10-719 Olsztyn

tel.: +48 8952342 58, fax: +48 895233937

e-mail: iwonab@uwm.edu.pl

\section{Introduction}

Peroxisome proliferator-activated receptors (PPARs) are members of the nuclear receptor family which belong to the steroid receptor superfamily. To date, three subtypes of these receptors, encoded by distinct genes, have been described as $\operatorname{PPAR} \alpha, \operatorname{PPAR} \beta$ (named also PPAR $\delta$ ) and PPAR $\gamma$ [1-3]. Moreover, three variants of PPAR $\gamma$, created by alternative promoter usage and splicing, have been characterized as $\gamma 1, \gamma 2$ and $\gamma 3$ [4].

PPARs create a structure typical for nuclear receptors and their activation requires heterodimerization with another nuclear receptor, 9-cis retinoic acid receptor (RXR). The heterodimer binds afterwards to a specific DNA sequence - peroxisome proliferator response element (PPRE), and activates transcription of various target genes. PPARs are modulated by numerous cofactors that enhance (as co-activators) or reduce (as co-inhibitors) their activity [5]. 
PPARs are ligand-dependent structures that are activated by natural and synthetic compounds. PPARs can also be activated in the absence of the ligand or by alternative pathways like the phosphorylation. Natural activators comprise unsaturated fatty acids, eicosanoids, prostaglandin (PG)-related compounds or oxidized lipids while a large group of synthetic ligands includes hypolipidemic drugs (fibrates), anti-inflammatory (e.g. indomethacin and fenoprofen) or insulin-sensitizing drugs (thiazolidinediones, TZDs) [6]. Moreover, a treatment with TZDs improves fertility through an induction of ovulation in women with polycystic ovary syndrome (PCOS) [8].

The presence of all PPAR isoforms has been found in various female reproductive tissues in different species. Experiments with knockout rodents suggest the role of PPARs in the regulation of reproductive functions. An inactivation of PPAR $\gamma$ indicated serious consequences that lead to the death of mouse embryo at an early stage of development [9]. PPAR $\beta$-null mice showed abnormalities in placenta development that increased embryos mortality [10]. The administration of the specific PPAR $\beta$ agonist reversed the implantation disorders in rats and it even increased the number of implanted embryos compared with the control group [11]. Rodents lacking PPAR $\alpha$ displayed a higher risk of maternal abortion and neonatal mortality [12]. In this review we attempt to summarize present knowledge and discuss the results on the role of PPARs in the regulation of reproductive functions in females.

\section{PPARs and the hypothalamic- -pituitary (HP) axis}

The expression of PPAR isoforms has been detected in mouse, ovine and human pituitary gland $[13,14]$ and in rodent hypothalamus [15], but their significance in the regulation of reproductive functions at the level of hypothalamic-pituitary (HP) remains poorly understood. It has been demonstrated that PPAR $\gamma$ activation by TZDs inhibited the development of pituitary adenomas in mice and humans $[18,19]$ but did not affect the secretion of prolactin (PRL), follicle-stimulating hormone (FSH) or luteinizing hormone (LH) by ovine pituitary or LH by murine LbetaT2 gonadotrophic pituitary tumor cell line [16]. However, recent data indicate a direct role for PPAR $\gamma$ in the modulation of pituitary function [18]. Rosiglitazone suppressed GnRH-mediated induction of LH and FSH genes expression and a conditional knockout of PPAR $\gamma$ in pituitary gonadotrophs caused an increase in LH levels in female mice and reduced litter size [18]. The presented above data suggest the involvement of PPARs in the regulation of reproductive processes at the HP axis but this knowledge is too narrow to define its specific role.

\section{PPARs in the ovary}

All PPAR isoforms are expressed in ovaries of different species including rodent, sheep, cow, pig, rabbit, buffalo and human [14, 19-21] but the role of gamma isoform has been studied most extensively compared with two other forms. Many studies have shown that PPARs gene and/or protein expression varies depending on ovarian cell type, physiological status and the species [14, 22-26]. It has also been frequently reported that PPARs are engaged in the regulation of various ovarian functions. A tissue-specific deletion of PPAR $\gamma$ in mouse ovary markedly reduced fertility [19]. Although these mice had a normal number of follicles and developed corpora lutea, progesterone $\left(\mathrm{P}_{4}\right)$ level was reduced, implantation rates were lower and litters were smaller [19]. An administration of PPAR $\gamma$ agonist for 4 weeks did not affect folliculogenesis, but increased plasma $\mathrm{P}_{4}$ concentration [27]. There is a lack of similar studies on the tissue-specific deletion of the two remaining PPAR isoforms.

\section{PPARs and remodeling of the ovarian tissue}

It has been demonstrated that PPAR $\gamma$ modulates follicular development, oocyte maturation, ovulation and the CL formation or regression [22, 28]. These effects are mediated by the regulation of several genes controlling angiogenesis, inflammatory response, apoptosis and cell cycle. It was suggested that PPAR $\gamma$ may be involved in ovulation and luteinization by inhibiting the secretion of pro-inflammatory cytokines such as tumor necrosis factor (TNF) $\alpha$ and interleukin (IL)-6 in human granulosa-lutein cells [29]. In ovarian macrophages, inducible nitric oxide synthase (NOS2), an important pro-inflammatory enzyme that regulates ovulation, was also reduced after treatment with PPAR $\gamma$ agonist [30].

There is evidence that PPAR $\gamma$ activation affected the proliferation of ovine granulosa cells but showed no impact on the apoptotic markers [14]. In turn, in rodent luteal and granulosa cells vitality was modulated by the regulation of anti-apoptotic bcl- 2 protein and tumor suppressor p53 expression [31,32]. PPARs may affect the expression and activity of proteases and angiogenic factors which are engaged in the tissue remodeling and the formation of follicular or luteal cells. Although the interaction between PPARs and matrix metalloproteinases (MMP-3, -9, -13), plasminogen activators, vascular endothelial growth factor (VEGF) and its receptors (Flt-1, Flt-2) as well 
as angiopoietin-like protein 4 (ANGPTL4) has been noted in various tissues including tumors [22,33], the existence of such association in ovarian tissue needs confirmation.

\section{PPARs and steroidogenesis}

PPARs appear to be important regulators of steroid $\left(\mathrm{P}_{4}\right.$ and $\left.\mathrm{E}_{2}\right)$ production. It has been frequently reported that activators of PPAR $\gamma$ regulate steroidogenesis in follicular cells of different species but the available results are contradictory. Stimulatory effect of synthetic or natural activators of PPAR $\gamma$ on $\mathrm{P}_{4}$ secretion was noted in mixed culture of human stromal, theca and granulosa cells [34], rat granulosa cells [35], ovine granulosa cells [14], porcine theca cells [20] and porcine follicles [36]. In turn, a lack of changes in $\mathrm{P}_{4}$ or $\mathrm{E}_{2}$ production was observed in human granulosa-lutein cells [29]. There are also studies showing an inhibitory effect of PPAR $\gamma$ activators on $\mathrm{P}_{4}$ production by cultured porcine and human $\mathrm{LH}$-stimulated granulosa cells $[37,38]$. Recent data showed that the activation of PPAR $\alpha$ and PPAR $\gamma$ affected steroidogenesis and follicle development in mouse preantral follicles treated with tumor necrosis factor alpha ( $\mathrm{TNF} \alpha)$, used as a model for studying follicle development in patients with PCOS [39]. Moreover, polymorphism in PPAR $\gamma$ gene is associated with metabolic disorders and abnormal blood $\mathrm{E}_{2}$ concentration in PCOS patients [40, 41].

There is a limited amount of studies showing the effect of PPARs activation on steroidogenesis in luteal cells. PPAR $\gamma$ agonists enhanced $\mathrm{P}_{4}$ production in bovine luteal cells collected during mid-luteal phase of the estrous cycle [42] or by corpora lutea explants of pseudopregnant rabbits [21]. However, there was no effect of PPAR $\gamma$ ligands on $\mathrm{P}_{4}$ production in hemisected and cultured rat CL [32]. Our recent results indicate that PPAR $(\alpha, \beta, \gamma)$ activators reduced $\mathrm{P}_{4}$ secretion by the CL explants during early stages (days 10-12 and 14-16) of pregnancy, whereas they were ineffective during the corresponding days of the estrous cycle [43]. Moreover, PPAR $\alpha$ agonist diminished $\mathrm{E}_{2}$ secretion by the CL explants collected during midand late-luteal phases of the estrous cycle and early pregnancy while natural or synthetic PPAR $\gamma$ ligands did not affect $\mathrm{E}_{2}$ release. In turn, $\operatorname{PPAR} \beta$ activation inhibited $\mathrm{E}_{2}$ release by the $\mathrm{CL}$ during early pregnancy, but did not affect the secretion during luteal phase of the estrous cycle [43]. The effect of PPAR ligands on steroidogenesis can be mediated by a modulation of steroidogenic enzymes action. However, inconsistency in their expression and activity has been often demonstrated by researchers. For instance, a stimulatory effect of PPAR $\gamma$ activation on steroidogenesis can be mediated by up-regulation of steroidogenic acute regulatory (StAR) protein in human and macaque granulosa cells $[44,45]$ or by $3 \beta$-HSD in porcine ovarian follicles [36]. An opposite effect of PPAR $\gamma$ ligands on $3 \beta$-HSD expression and $\mathrm{P}_{4}$ release was observed in porcine granulosa cells [37]. There are also studies showing that PPAR $\gamma$ or PPAR $\alpha$ activation inhibited aromatase expression in human granulosa cells and mouse ovary [46, 47]. Different studies, including ours, indicate that changes in steroids production evoked by PPAR ligands are not always followed by alternations in genes or proteins expression of $3 \beta$-HSD in porcine endometrium and ovine granulosa cells [14, 43], CYP11A1 in ovine granulosa cells [14] or CYP17 in porcine theca cells [20]. The discrepancies in steroids production or expression of enzymes responsible for steroids synthesis could be a result of differences in species, ovarian cells type, physiological status, type and dose of PPAR ligands, time of the tissue incubation with the treatments.

The above results revealed that PPARs are engaged in the regulation of various ovarian functions in different species. They also suggest a different receptivity of the tissue to PPAR agonists depending on physiological status of individuals. However, molecular mechanisms of PPARs, especially alpha and beta isoforms, action in the ovary still remains not fully understood. Because certain PPAR ligands are clinically used to treat diabetes or polycystic ovary syndrome (PCOS), the understanding of their exact role in the ovary should be an important reason of interest.

\section{PPARs in the uterus}

Compared to the research on PPARs in the ovary, the studies on their functions in the uterus are limited. Most experiments were carried out in the endometrium, where several essential events occur intended for preparation of the tissue to the embryo implantation, placentation and pregnancy sustain. The expression of all PPAR isoforms has been demonstrated in human, bovine, ovine, porcine and rodent endometrial tissue [48-50].

Previously published data indicate that $\operatorname{PPAR} \alpha$ and PPAR $\beta$ expression markedly increased in rodent endometrial stroma at the beginning of implantation [50] while PPAR $\gamma$ mRNA level was higher during fertilization but declined at the beginning of implantation [50]. In the endometrium of pregnant cows, a lack of differences in PPAR $\gamma$ mRNA level was noted [51], while in ovine endometrium the expression of PPAR $\beta$ stayed at a constant level on days 7-17 (peri-implantation period), PPAR $\gamma$ declined from days 7 to 17 and PPAR $\gamma$ peaked 
first at day 9 and then on day 17 [49]. Differences in PPAR $\beta$ and PPAR $\gamma$ gene expression were also reported in porcine endometrium [52]. A higher expression of PPAR $\beta$ was reported on day 15 of the estrous cycle (during luteolysis) compared with days 15 and 25 of pregnancy (peri-implantation period). In turn, the transcript level of PPAR $\gamma$ was elevated during the tested days of pregnancy compared with the level on day 15 of the estrous cycle [52]. The results of our studies [26] showed increased mRNA levels of $\operatorname{PPAR} \alpha$ and $\operatorname{PPAR} \beta$ during the luteal phase compared with the follicular phase of the estrous cycle. During pregnancy, the decreased $\operatorname{PPAR} \alpha$ and $\operatorname{PPAR} \beta$ mRNA levels were noted on days 11-12 (the time of maternal recognition of pregnancy) and higher on days 13-15, at the beginning of implantation. In turn, the PPAR $\gamma$ gene expression was higher on days $13-15$ of the estrous cycle (during luteolysis) than on the remaining days while during pregnancy the transcript level was increased on days 16-30 of pregnancy (peri-implantation period) compared with days 5-15 [26]. In another experiment performed on gilts subjected to surgical procedures, we reported markedly increased mRNA levels of $\operatorname{PPAR} \alpha$ and $\operatorname{PPAR} \beta$, but not PPAR $\gamma$, in the endometrium collected from the uterine horn with fetuses on day 14 of pregnancy compared to the horn without embryos [53].

The above results have shown that uteri of different mammal species express all PPAR isoforms. The discrepancy in their expression pattern, which was often reported, can be related to physiological status of individuals or species. Differential PPARs expression profile during various reproductive conditions suggest their involvement in the regulation of uterine secretory function which can be crucial for luteolysis of the CL during the estrous cycle or the embryo implantation during pregnancy. PPARs effect at the endometrial level can be mediated by a number of ways.

\section{Interactions between PPARs and prostaglandins (PGs)}

The endometrial tissue is a place where PPARs can regulate the expression and activity of prostaglandin endoperoxidase synthase 2 (PTGS2, COX-2, PTGH) - a rate-limiting enzyme responsible for PGs synthesis. Endometrial PTGS-derived $\mathrm{PGF}_{2 \alpha}$ and $\mathrm{PGE}_{2}$ are crucial in the regulation of the CL activity through respective luteolytic or luteotrophic actions in various species [54, 55]. PGs significance has been highlighted in the regulation of ovulation, the CL functions, maternal recognition of pregnancy, implantation and parturition [56]. Recently, the role of PTGS-derived $\mathrm{PGI}_{2}$ (prostacyclin) has been reported in the regu- lation of blastocyst development, embryo hatching and the implantation course in mice and pigs $[57,58]$.

It has been suggested that there is a direct interaction between PGs and PPARs, because PPAR response element was identified in the PTGS2 gene promoter [59] and the activation of PPARs affected PTGS2 expression in various cell or tissue types including human [60] and bovine endometrial cells [48, 61], WISH cells line and primary amnion cells [62]. The administration of different $\operatorname{PPAR} \beta$ agonists to the PTGS2 deficient mice restored reduced implantation rates what indicates a direct interaction between these pathways [63]. In addition, the treatment of bovine endometrial cells with $\operatorname{PPAR} \alpha$ and $\operatorname{PPAR} \beta$ activators enhanced both $\mathrm{PGE}_{2}$ and $\mathrm{PGF}_{2 \alpha}$ production [48]. Our studies showed that PPAR $\alpha, \operatorname{PPAR} \beta$ and PPAR $\gamma$ agonists stimulated $\mathrm{PGF}_{2 \alpha}$ secretion by porcine endometrium during mid- and late-luteal phase of the estrous cycle whereas the ligands were less effective during the corresponding days of pregnancy. In addition, the tested PPAR agonists did not affect PGFS gene expression during luteal phase of the estrous cycle, but they modulated the enzyme mRNA level during peri-implantation [64]. This suggests different sensitivity of porcine endometrium to PPAR ligands associated with the physiological status of animals.

We have recently reported that PPARs are mediators of $\mathrm{PGE}_{2}$ production in the porcine endometrium during the luteal phase of the estrous cycle and the time of peri-implantation. Ligands of PPAR $\gamma$ or $\operatorname{PPAR} \beta$ enhanced both the synthesis and accumulation of $\mathrm{PGE}_{2}$ in culture media depending on the phase of the estrous cycle or pregnancy, whereas PPAR ligands were less effective in $\mathrm{PGE}_{2}$ production [65].

As mentioned before, PPARs can interact with $\mathrm{PGI}_{2}$ and certain $\mathrm{PGI}_{2}$ analogues can act as ligands for the PPAR $\beta$. This ability suggests that the effects of $\mathrm{PGI}_{2}$ may be mediated by PPAR $\beta$ in mouse, rat and sheep uterus [49, 66, 67]. An interaction between $\mathrm{PGI}_{2}$ and $\mathrm{PPAR} \beta$ facilitated implantation in mouse by increasing the number of implanted embryos [63]. It has been recently reported that $\mathrm{PGI}_{2}$-induced $\operatorname{PPAR} \beta$ activation accelerated blastocyst hatching in mice [57] and a deletion of PPAR $\beta$ at early stages of preimplantation of mouse embryos caused a delay of blastocyst hatching.

\section{Interactions between PPARs and steroids}

Apparently, steroids $\left(\mathrm{P}_{4}\right.$ and $\left.\mathrm{E}_{2}\right)$ are crucial regulators of architectonical alterations in the uterine structures. They regulate cell proliferation, differentiation and remodeling of various uterine cell types depending on the female physiological status [68]. The CL is the main source of steroid hormones in the uterine tissue, 
although steroidogenic activity of the endometrium has been also reported [69]. There are available data documenting a possible interaction between steroids and PPARs in the uterus. PPAR $\gamma$ activation increased mouse uterine mass, proliferation and evoked morphogenetic alterations in the tissue [70]. PPARs can bind to the estrogen response element (ERE) in targeted genes and act as a regulator of the estrogen receptor (ER) expression [71]. There is evidence that $\operatorname{PPAR} \alpha$ or PPAR $\gamma$ activation affected the protein level of ER $\gamma$ in all mouse uterine compartments [70]. It has been suggested that PPAR $\gamma$ activation increases proliferative estrogen action and facilitates estrogen-dependent endometrial hyperplasia but $\operatorname{PPAR} \alpha$ activation has an opposite effect - attenuates estradiol impact on the uterus by reducing cell proliferative capacity [70].

PPARs can also be engaged in steroids synthesis in the endometrial tissue. Our unpublished results suggest that the receptors can mediate $\mathrm{P}_{4}$ and $\mathrm{E}_{2}$ production in porcine endometrial explants depending on the physiological status of animals. For instance, an inhibitory effect of PPAR ( $\alpha, \beta, \gamma$ isoforms) agonists on $\mathrm{P}_{4}$ release was noted during mid-luteal phase of the estrous cycle but not in late-luteal phase. In addition, $\operatorname{PPAR} \alpha$ and PPAR $\gamma$ agonists reduced $\mathrm{E}_{2}$ secretion during early pregnancy while $\operatorname{PPAR} \beta$ and $\operatorname{PPAR} \gamma$ activation increased the secretion during luteal phase of the estrous cycle.

\section{Interactions between PPARs and cytokines}

It has been frequently reported, that cytokines, mediators of immune response, are important regulators of reproductive functions. Their significance has been described during the estrous/menstrual cycle, but majority of the studies focused on their role during implantation, when the regulation of maternal immune response to an antigenically different embryo is required. The endometrium secretes a number of cytokines such as IL-1, IL-6, leukemia inhibitory factor (LIF), colony stimulating factor 1 (CSF-1), TNF $\alpha$ [72]. They are engaged in the preparation of endometrium for the embryo implantation, PGs synthesis, trophoblast elongation, placenta development and pregnancy maintenance $[69,73]$. Uterine disorders such as inflammation, adenomyosis, endometriosis are accompanied by altered number of cells synthetizing cytokines and an unbalanced amount of secreted cytokines $[74,75]$.

Interactions between PPARs and cytokines have been frequently suggested though most researchers described PPARs as significant immunomodulators in non-reproductive cells or tissues [76]. Only two groups of researchers reported that PPAR $\gamma$ ligands modulat- ed the secretion of IL-1, IL-6, IL-8 or colony stimulating factor-1 (CSF-1) by human endometrial cells [77, 78]. Contrary, a modulatory effect of cytokines on PPARs activity has also been reported. The results of our studies indicate that IL- 6 and interferon $\gamma$ (IFN $\gamma$ ) had an impact on PPARs gene expression in the porcine endometrium on day 14 of the estrous cycle or pregnancy [79]. We demonstrated a very weak effect of the cytokines during the estrous cycle, but a strong effect during pregnancy. IFN $\gamma$ affected the expression of all PPAR isoforms while IL-6 influenced only PPAR $\gamma$ gene expression [79].

There are some reports suggesting that PPAR $\gamma$ plays an important role in the regulation of inflammatory processes in the endometrium [80] and the inhibition of the immune response expressed by a decreased synthesis of IL- 6 and IL- 8 could be effectively used to treat endometriosis in women [78]. Further research is required to find out whether PPARs are involved in the regulation the synthesis of cytokines - factors that modulate mother's immune response during early pregnancy (physiological state) and if they are an important link in the course of inflammatory processes in the female reproductive system (pathological state).

\section{PPARs in the placenta}

Human and animal studies have shown that PPARs play a regulatory role in placental development and functions [81-83]. Three isoforms of PPARs have been detected in placentas of a limited number of species including mouse, rat, ovine and human [49, 84, 85]. Recently, PPAR $\gamma$ expression has been also confirmed in bovine throphoblast [86]. Depending on the species and pregnancy stage, PPARs display a different expression in diverse compartments of the placenta $[82,87,88]$.

It has been frequently reported that the principal role in human and rodent placenta development is played by PPAR $\gamma$. In rodents, the role of PPAR $\gamma$ in trophoblast differentiation, maturation and invasion seems to be established. PPAR $\gamma$ expression in rat placenta was high on day 13 , during placental differentiation and maturation, and later significantly declined [85]. In addition, oral administration of PPAR $\gamma$ ligand enhanced PPAR $\gamma$ transcript level in the rat placenta and decreased embryos mortality by half [85]. Mice lacking this isoform (PPAR $\left.\gamma^{--}\right)$die on day 10 of gestation due to the defects in trophoblast differentiation, placental vascularization and nutritional transport to the developing embryos [89]. Recent reports indicate that in fully viable PPAR $\gamma$-null mice, obtained through specific and total epiblastic gene deletion, the placental vasculature defects, which 
are associated with unbalanced expression of pro- and antiangiogenic factors, might be a major reason of embryonic lethality [90]. In the same study the authors indicated that PPAR $\gamma$ activation affected mouse placental microvasculature and the layers organization by the regulation of proangiogenic genes expression such as proliferin (PLF), vascular endothelial growth factor (VEGF) and platelet-endothelial cell adhesion molecule-1 (Pecam1) [90]. PPAR $\gamma$ affects rodent trophoblast differentiation by interaction with various coactivators such as PPAR-binding protein (PBP) and PPAR-interacting protein (PRIP) [91]. In addition, the important role of PPAR $\gamma$ in placental development depends on the expression of anti-adhesive molecule Muc1, which is expressed in placenta, but not in other tissues such as adipocytes [92].

In humans, the role of PPAR $\gamma$ in placental development is less clear and the results of mainly in vitro experiments have not been always consistent. Available data indicate that PPAR $\gamma$ activation modulates the differentiation of cytotrophoblast into syncytiotrophoblast [93]. It has been also suggested that PPAR $\gamma$-dependent trophoblast differentiation process is mediated by the increase of chorionic gonadotropin beta-subunit (hCG $\beta$, biochemical marker of trophoblast differentiation) expression and secretion as well as by the synthesis of human placental lactogen (hPL), human placental growth hormone (hPGH) and leptin [93]. Interestingly, whereas the exposure of cultured primary trophoblasts to synthetic PPAR $\gamma$ ligand enhanced trophoblast differentiation, the natural ligand had opposite effect and promoted trophoblast apoptosis through p53 up-regulation [94].

PPAR $\gamma$ plays an important role in the trophoblast invasion. Tarrade et al. [95] reported that PPAR $\gamma$ is highly expressed in human cytotrophoblasts at the feto-maternal interface, particularly in the extravillous cytotrophoblasts involved in uterus invasion. They also showed that both synthetic and natural PPAR $\gamma$ agonists inhibited extravillous cytotrophoblast invasion and the treatment with PPAR $\gamma$ antagonist facilitated the invasion process [95]. Recently, the analysis of PPAR $\gamma$-target genes in human trophoblast led to characterization of new factors engaged in the regulation of trophoblast invasion $[82,83,96]$. Among those, heme-oxygenase-1 (HO-1), human placental growth hormone (hPGH), the pregnancy-associated plasma protein (PAPP-A) and hCG seems to have a significant role in this process [97-99]. Moreover, the role of PPARs in the immune response and immunotolerance during trophoblast invasion cannot be neglected [100]. Indeed, there is evidence showing PPAR $\gamma$-dependent inhibition of the production of cytokines such as IL-1 $\beta$, IL-6, IL-8, IL-10 and TNF $\alpha$ in human placenta as well as in amnion and choriodecidua [101]. An important relationship between cytokines and PPARs can be suggested during the beginning of parturition when an increased production of pro-inflammatory cytokines [102] correlates with changes in PPARs expression in human placental tissues [88].

One should also not disregard the importance of PPAR $\gamma$ in the regulation of placental lipid homeostasis even if available data are limited. Transfer of fatty acids from the mother to the fetus is absolutely necessary for a proper embryo development, implantation, placenta development, and pregnancy maintenance $[103,104]$. Various proteins engaged in fatty acid binding, transport, $\beta$-oxidation and lipid accumulation are expressed in the placental tissue [105]. It has been suggested that the absence of PPAR $\gamma$ or PPAR $\beta$ might lead to the defects of placenta and fetus development due to an impaired placental/fetal fatty acid homeostasis [10]. The activation of PPAR $\gamma$ regulates fatty acid uptake and lipid storage in primary human trophoblasts. This effect was characterized by an increased expression of genes encoding fatty acid transporters (FATP1 and FATP2) and a fat droplet associated protein, adipophilin [81, 106]. There are also reports suggesting a possible role of PPARs in the regulation of proteins involved in placental fatty acid/lipids metabolism such as cytochrome P450 4A (CYP4A), cyclooxygenases and lipooxygenases (LOX) [105].

Although the role of PPAR $\gamma$ in placental development is significant and unquestionable, there is evidence that $\operatorname{PPAR} \beta$ can also be an important player in this process. As mentioned before, a lack of PPAR in the rodent model resulted in severe placenta defects caused mainly by the loss of connection between the placenta and decidua [10]. In comparison to wild-type animals PPAR $\beta^{-/}$pregnant mice exhibited smaller placental labyrinth, maternal bleeding to the labyrinth and increased fetal mortality [10]. PPAR $\beta$ is involved in trophoblast growth by regulating differentiation of trophoblast giant cells via PI3K/Akt pathway that is important in the blastocyst implantation, alteration of the maternal decidua structure and secretion of hormones such as placental lactogens I and II (PL-I, PL-II) and proliferin [107].

While the role of PPAR $\gamma$ in trophoblast differentiation, invasion and placental functions have been extensively studied in human and rodent models, the involvement of other PPAR isoforms has not been not fully explained. In addition, most studies have only been performed in humans and rodents having invasive placentas. Therefore, it is reasonable to conduct similar studies in mammals with non-invasive placentas, occurring in domestic animals such as pigs, cows and 
Table 1. The involvement of PPARs in the regulation of female reproductive processes in different tissues

\begin{tabular}{|c|c|c|c|}
\hline & $\operatorname{PPAR} \alpha$ & PPAR $\beta$ & $\mathbf{P P A R} \gamma$ \\
\hline $\begin{array}{l}\text { Hypothalamic-pituitary } \\
\text { (HP) axis }\end{array}$ & - & - & $\begin{array}{l}\text { Gonadotrophins (LH and FSH) } \\
\text { synthesis }\end{array}$ \\
\hline \multirow{4}{*}{ Ovary } & \multicolumn{3}{|c|}{ Steroids (P4 and E2) synthesis } \\
\hline & - & - & $\begin{array}{l}\text { Ovulation and luteinisation through } \\
\text { the regulation of TNF } \alpha \text { and IL-6 }\end{array}$ \\
\hline & $\begin{array}{l}\text { Tissue remodeling through the } \\
\text { regulation of MMP-9 }\end{array}$ & - & $\begin{array}{l}\text { Tissue remodeling through } \\
\text { the regulation of MMP- } 3,-9,-13 \text {, } \\
\text { plasminogen activators }\end{array}$ \\
\hline & - & - & $\begin{array}{l}\text { Angiogenesis through the regulation } \\
\text { of VEGF, its receptors (Flt-1, Flt-2) } \\
\text { and ANGPTL4 }\end{array}$ \\
\hline \multirow{5}{*}{ Uterus } & \multicolumn{3}{|c|}{ Steroids (P4 and E2) release } \\
\hline & \multicolumn{3}{|c|}{ PGE2 and PGF2 $\alpha$ synthesis } \\
\hline & - & $\begin{array}{l}\text { Number of implanted embryos } \\
\text { by PGI2 modulation }\end{array}$ & - \\
\hline & - & - & $\begin{array}{c}\text { Cytokines (IL-1, IL-6, IL-8, CSF-1) } \\
\text { release }\end{array}$ \\
\hline & Estrogen signalling pathway & - & - \\
\hline \multirow{6}{*}{ Placenta } & - & - & $\begin{array}{c}\text { Trophoblast invasion by the regula- } \\
\text { tion of HO-1, hPGH, PAPP-A and } \\
\text { hCG as well as cytokines } \\
\text { (IL-1 } \beta, \text { IL-6, IL-8, IL-10 and TNF } \alpha \text { ) }\end{array}$ \\
\hline & - & \multicolumn{2}{|c|}{ Trophoblast differentiation by the regulation of PBP and PRIP } \\
\hline & - & - & $\begin{array}{l}\text { Trophoblast vascularisation by the } \\
\text { regulation of Prl2c2, PLF, VEGF } \\
\text { and Pecam } 1\end{array}$ \\
\hline & - & $\begin{array}{l}\text { Trophoblast growth by PI3K/Akt } \\
\text { pathway }\end{array}$ & - \\
\hline & - & \multicolumn{2}{|c|}{$\begin{array}{c}\text { Fatty acid uptake and lipids storage through the regulation of fatty } \\
\text { acid transporters (FATP1, FATP2) and a fat droplet associated } \\
\text { protein, adipophilin }\end{array}$} \\
\hline & - & \multicolumn{2}{|c|}{$\begin{array}{l}\text { Fatty acid/lipids metabolism through the regulation } \\
\text { of CYP4A, COX and LOX }\end{array}$} \\
\hline \multirow{4}{*}{ Embryo } & - & \multicolumn{2}{|c|}{ Embryo implantation by the effect on fatty acid metabolism } \\
\hline & $\begin{array}{l}\text { Long-term foetal adaptations to } \\
\text { the maternal diet by epigenetic } \\
\text { control of energy metabolism }\end{array}$ & \multicolumn{2}{|c|}{$\begin{array}{l}\text { Short-term foetal adaptations to the maternal diet by the control } \\
\text { of cell growth and differentiation }\end{array}$} \\
\hline & - & - & Neurons differentiation \\
\hline & - & Prevents neuronal death & - \\
\hline
\end{tabular}

'_- - lack of data concerning PPARs effect on reproductive tissues; COX — cyclooxygenases; CSF-1 - colony stimulating factor 1; CYP4A cytochrome P450 4A; $\mathrm{E}_{2}$ — estradiol; FATP — fatty acid transporters; Flt — fms-related tyrosine kinase; angiopoietin-like 4 protein; FSH — follicle-stimulating hormone; hCG - human chorionic gonadotropin; HO-1 - heme-oxygenase-1; hPGH - human placental growth hormone; IL — interleukin; LH — luteinizing hormone; LOX — lipooxygenases; MMP — matrix metalloproteinase; $\mathrm{P}_{4}$ - progesterone; PAPP-A — the pregnancy-associated plasma protein; PBP — PPAR-binding protein; Pecam1 — platelet/endothelial cell adhesion molecule 1; PGE $_{2}$ - prostaglandin $\mathrm{E}_{2} ; \mathrm{PGF}_{2 \alpha}$ - prostaglandin $\mathrm{F}_{2 \alpha} ; \mathrm{PGI}_{2}$ — prostaglandin $\mathrm{I}_{2}$ /prostacyclin; PI3K/Akt — phosphatidylinositol-3 kinase/RAC-alpha serine/threonine-protein kinase; PLF — proliferin; PRIP — PPAR-interacting protein; Prl2c2 - prolactin family 2, subfamily c, member 2; TNF $\alpha$ - tumor necrosis factor $\alpha$; VEGF — vascular endothelial growth factor

mares. Moreover, further studies are also required for a better understanding of the role of PPARs in the regulation of fatty acid homeostasis, angiogenesis and inflammatory responses during pregnancy.

\section{PPARs in the embryo}

The expression of all PPARs has been found in bovine, human and mouse embryos $[108,109]$. PPAR $\beta$ 
and PPAR $\gamma$ facilitate the embryo implantation and placenta development through the effect on lipids, carbohydrates and amino-acids metabolism. Produced metabolites can be used by the fetus as substrates for energy metabolism, synthesis of the membranes and signaling molecules [110]. Interestingly, the fetal adaptations to the maternal diet might be regulated by two mechanisms. The first, short-term, mediated by PPAR $\beta$ and $\mathrm{PPAR} \gamma$ regulates cell growth and differentiation, while the second one, long-term, mediated by PPAR $\alpha$ seems to be related to the epigenetic control of energy metabolism to optimize postnatal survival [110].

$\operatorname{PPAR} \alpha$ was also described as an important regulator of lipid catabolism in fetal liver and heart [111, 112]. An additional role of PPARs has been revealed during the development of embryonic nervous system. An activation of PPAR $\gamma$ by natural agonists promoted neuronal differentiation in 17-day-old rat fetuses [113]. In addition, PPAR $\beta$ agonist prevented inflammation-induced neuronal death in microglia-neuron in in vitro co-cultures [114]. Based on the above results, it seems that PPARs play a significant role during the embryonic development. However, it has to be noted that general scarcity of data should encourage researchers to conduct studies in this field.

\section{Conclusions}

PPARs are expressed at different levels of hypothalamic-pituitary-gonadal axis. They are also present in the uterus as well as in the placenta and embryonic tissues of different species. Such an extensive distribution in the above tissues indicates an important role of PPARs in the regulation of various reproductive functions (Table 1). Despite numerous studies concerning the expression and the role of PPARs in the modulation of female reproductive processes, several physiological and molecular properties of these receptors still remain unexplored. The understanding of the mechanisms that control the course of estrous/menstrual cycle, early pregnancy maintenance and gestation progress may contribute to an increase in the reproductive rates and improve economic parameters of farming animals. In addition, taking into consideration a fact, that certain PPAR ligands are used clinically to improve reproductive disorders, a precise understanding of PPARs' action in various reproductive tissues should be a significant reason for conducting more studies.

\section{Acknowledgments}

This work was supported by the State Committee for Scientific Research (Project N N311 360235 and UWM grant 5280206 806).

\section{References}

1. Issemann I, Green S. Activation of a member of the steroid hormone receptor superfamily by peroxisome proliferators. Nature. 1990;347:645-650. doi: 10.1038/347645a0.

2. Kliewer SA, Forman BM, Blumberg B et al. Differential expression and activation of a family of murine peroxisome proliferator-activated receptors. Proc Natl Acad Sci USA. 1994;91:7355-7359. doi: 10.1073/pnas.91.15.7355.

3. Dreyer C, Krey G, Keller Het al. Control of peroxisomal beta-oxidation pathway by a novel family of nuclear hormone receptors. Cell. 1992;68:879-887. doi: 10.1016/0092-8674(92)90031-7.

4. Janani C, Ranjitha Kumari BD. PPAR gamma gene a review. Diabetes Metab Syndr. 2015;9:46-50. doi: 10.1016/j. dsx.2014.09.015.

5. Lalloyer F, Staels B. Fibrates, glitazones, and peroxisome proliferator-activated receptors. Arterioscler Thromb Vasc Biol. 2010;30:894-899. doi: 10.1016/j.dsx.2014.09.015.

6. Viswakarma N, Jia Y, Bai L et al. Coactivators in PPAR-regulated gene expression. PPAR Res. 2010;2010:250126. doi: 10.1155/2010/250126.

7. Abbas A, Blandon $\mathrm{J}$, Rude $\mathrm{J}$ et al. PPAR- $\gamma$ agonist in treatment of diabetes: cardiovascular safety considerations. Cardiovasc Hematol Agents Med Chem. 2012;10:124-134. doi: 10.2174/187152512800388948.

8. Nestler JE, Stovall D, Akhter N et al. Strategies for the use of insulin-sensitizing drugs to treat infertility in women with polycystic ovary syndrome. Fertil Steril. 2002;77:209-215. doi: 10.1016/S0015-0282(01)02963-6.

9. Barak Y, Nelson MC, Ong E et al. PPAR $\gamma$ is required for placental, cardiac, and adipose tissue development. Mol Cell. 1999;4:585-595. doi: 10.1016/S1097-2765(00)80209-9.

10. Barak Y, Liao D, He W et al. Effects of peroxisome proliferator-activated receptor delta on placentation, adiposity, and colorectal cancer. Proc Natl Acad Sci USA. 2002;99: 303-308. doi: 10.1073/pnas.012610299.

11. Lim H, Dey SK. PPAR delta functions as a prostacyclin receptor in blastocyst implantation. Trends Endocrinol Metab. 2000;11:137-142. doi: 10.1016/S1043-2760(00)00243-5.

12. Yessoufou A, Hichami A, Besnard P et al. Peroxisome proliferator-activated receptor alpha deficiency increases the risk of maternal abortion and neonatal mortality in murine pregnancy with or without diabetes mellitus: Modulation of T cell differentiation. Endocrinology. 2006;147:4410-4418. doi: 10.1210/en.2006-0067.

13. Bogazzi F, Russo D, Locci MT et al. Peroxisome proliferator-activated receptor (PPAR)gamma is highly expressed in normal human pituitary gland. $J$ Endocrinol Invest. 2005;28:899-904. doi: 10.1007/BF03345321.

14. Froment $\mathrm{P}$, Fabre S, Dupont $\mathrm{J}$ et al. Expression and functional role of peroxisome proliferator-activated receptor-gamma in ovarian folliculogenesis in the sheep. Biol Reprod. 2003;69:1665-1674. doi: 10.1677/joe.1.06667.

15. Sarruf DA, Yu F, Nguyen HT et al. Expression of peroxisome proliferator-activated receptor-gamma in key neuronal subsets regulating glucose metabolism and energy homeostasis. Endocrinology. 2009;150:707-712. doi: 10.1210/en.2008-0899.

16. Heaney AP, Fernando M, Melmed S. PPAR-gamma receptor ligands: novel therapy for pituitary adenomas. J Clin Invest. 2003;111:1381-1388. doi: 10.1172/JCI200316575.

17. Winczyk K, Kunert-Radek J, Gruszka A et al. Effects of rosiglitazone-peroxisome proliferators-activated receptor gamma (PPARgamma) agonist on cell viability of human pituitary adenomas in vitro. Neuro Endocrinol Lett. 2009;30:107-110. PMID: 19300395.

18. Sharma S, Sharma PM, Mistry DS et al. PPARG regulates gonadotropin-releasing hormone signaling in LbetaT2 cells in 
vitro and pituitary gonadotroph function in vivo in mice. Biol Reprod. 2011;84:466-475. doi: 10.1095/biolreprod.110.088005.

19. Cui Y, Miyoshi K, Claudio E et al. Loss of the peroxisome proliferation-activated receptor gamma (PPARgamma) does not affect mammary development and propensity for tumor formation but leads to reduced fertility. J Biol Chem. 2002;277:17830-1785. doi: 10.1074/jbc.M200186200.

20. Schoppee PD, Garmey JC, Veldhuis JD. Putative activation of the peroxisome proliferator-activated receptor gamma impairs androgen and enhances progesterone biosynthesis in primary cultures of porcine theca cells. Biol Reprod. 2002;66:190-198. doi: 10.1095/biolreprod66.1.190.

21. Zerani M, Maranesi M, Brecchia G et al. Evidence for a luteotropic role of peroxisome proliferator-activated receptor gamma: expression and in vitro effects on enzymatic and hormonal activities in corpora lutea of pseudopregnant rabbits. Biol Reprod. 2013;88:62. doi: 10.1095/biolreprod.112.107383.

22. Komar CM. Peroxisome proliferator-activated receptors (PPARs) and ovarian function - implications for regulating steroidogenesis, differentiation, and tissue remodeling. Reprod Biol Endocrinol. 2005;3:41. doi: 10.1186/1477-7827-3-41.

23. Dupont J, Chabrolle C, Ramé C et al. Role of the peroxisome proliferator-activated receptors, adenosine monophosphate-activated kinase, and adiponectin in the ovary. PPAR Res. 2008;2008:176275. doi: 10.1155/2008/176275.

24. Komar CM, Curry TE Jr. Localization and expression of messenger RNAs for the peroxisome proliferator-activated receptors in ovarian tissue from naturally cycling and pseudopregnant rats. Biol Reprod. 2002;66:1531-1539. doi: $10.1095 /$ biolreprod66.5.1531.

25. Viergutz T, Loehrke B, Poehland R et al. Relationship between different stages of the corpus luteum and the expression of the peroxisome proliferator-activated receptor gamma protein in bovine large lutein cells. J Reprod Fertil. 2000;118:153-161. doi: 10.1530/reprod/118.1.153.

26. Bogacka I, Bogacki M. The quantitative expression of peroxisome proliferator activated receptor (PPAR) genes in porcine endometrium through the estrous cycle and early pregnancy. J Physiol Pharmacol. 2011;62:559-565. PMID: 22204804.

27. Lebovic DI, Kir M, Casey CL. Peroxisome proliferator-activated receptor-gamma induces regression of endometrial explants in a rat model of endometriosis. Fertil Steril. 2004;82:1008-1013. doi: 10.1016/j.fertnstert.2004.02.148.

28. Froment P, Gizard F, Defever D et al. Peroxisome proliferator-activated receptors in reproductive tissues: from gametogenesis to parturition. J Endocrinol. 2006;189:199-209. doi: $10.1677 /$ joe.1.06667.

29. Chen Q, Sun X, Chen J et al. Direct rosiglitazone action on steroidogenesis and proinflammatory factor production in human granulosa-lutein cells. Reprod Biol Endocrinol. 2009;7:147. doi: 10.1186/1477-7827-7-147.

30. Minge CE, Ryan NK, Van Der Hoek KH et al. Troglitazone regulates peroxisome proliferator-activated receptors and inducible nitric oxide synthase in murine ovarian macrophages. Biol Reprod. 2006;74:153-160. doi: 10.1095/biolreprod.105.043729.

31. Lovekamp-Swan T, Chaffin CL. The peroxisome proliferator-activated receptor gamma ligand troglitazone induces apoptosis and p53 in rat granulosa cells. Mol Cell Endocrinol. 2005;233:15-24. doi: 10.1016/j.mce.2005.01.011.

32. Tinfo N, Komar C. Potential role for peroxisome proliferator-activated receptor gamma in regulating luteal lifespan in the rat. Reproduction. 2007;133:187-196. doi: 10.1530/REP-06-0134.

33. Margeli A, Kouraklis G, Theocharis S. Peroxisome proliferator activated receptor-gamma (PPAR-gamma) ligands and angiogenesis. Angiogenesis. 2003;6:165-169. doi: 10.1023/B:AGEN.0000021377.13669.c0.

34. Seto-Young D, Paliou M, Schlosser J et al. Direct thiazolidinedione action in the human ovary: insulin-independent and insulin-sensitizing effects on steroidogenesis and insulin-like growth factor binding protein-1 production.J Clin Endocrinol Metab. 2005;90:6099-6105. doi: 10.1210/jc.2005-0469.

35. Komar CM, Braissant O, Wahli W et al. Expression and localization of PPARs in the rat ovary during follicular development and the periovulatory period. Endocrinology. 2001;142:4831-4838. doi: 10.1210/endo.142.11.8429.

36. Rak-Mardyła A, Karpeta A. Rosiglitazone stimulates peroxisome proliferator-activated receptor gamma expression and directly affects in vitro steroidogenesis in porcine ovarian follicles. Theriogenology. 2014;82:1-9. doi: 10.1016/j.theriogenology.2014.02.016.

37. Gasic S, Bodenburg Y, Nagamani M et al. Troglitazone inhibits progesterone production in porcine granulosa cells. Endocrinology. 1998;139:4962-4926. doi: 10.1210/endo.139.12.6385.

38. Willis D, Mason H, Gilling-Smith $\mathrm{C}$ et al. Modulation by insulin of follicle-stimulating hormone and luteinizing hormone actions in human granulosa cells of normal and polycystic ovaries. J Clin Endocrinol Metab. 1996;81:302-309. doi: $10.1210 /$ jcem.81.1.8550768.

39. Hara S, Takahashi T, Igarashi $\mathrm{H}$ et al. Peroxisome proliferator-activated receptor- $\gamma$ agonists prevent Tumor Necrosis Factor- $\alpha$-mediated inhibition of FSH-induced follicle development and estradiol production in a preantral follicle culture system.J Mamm Ova Res. 2014;31:2-11. doi: 10.1274/ imor.31.2.

40. Shaikh N, Mukherjee A, Shah N et al. Peroxisome proliferator activated receptor gamma gene variants influence susceptibility and insulin related traits in Indian women with polycystic ovary syndrome. J Assist Reprod Genet. 2013;30:913-921. doi: $\underline{10.1007 / \mathrm{s} 10815-013-0025-\mathrm{y}}$.

41. Yang J, Gong H, Liu W et al. The association of Pro12Ala polymorphism in the peroxisome proliferator-activated receptor-gamma2 gene with the metabolic characteristics in Chinese women with polycystic ovary syndrome. Int J Clin Exp Pathol. 2013;6:1894-1902. PMID: 24040456.

42. Löhrke B, Viergutz T, Shahi SK et al. Detection and functional characterisation of the transcription factor peroxisome proliferator-activated receptor gamma in lutein cells. J Endocrinol. 1998;159:429-439. doi: 10.1677/joe.0.1590429.

43. Kurzynska A, Bogacki M, Chojnowska K et al. Peroxisome proliferator activated receptor ligands affect progesterone and $17 \beta$-estradiol secretion by porcine corpus luteum during early pregnancy. J Physiol Pharmacol. 2014;65:709-717. PMID: 25371531.

44. Seto-Young D, Avtanski D, Strizhevsky M et al. Interactions among peroxisome proliferator activated receptor-gamma, insulin signaling pathways, and steroidogenic acute regulatory protein in human ovarian cells. J Clin Endocrinol Metab. 2007;92:2232-2239. doi: 10.1210/jc.2006-1935.

45. Puttabyatappa M, Vandevoort CA, Chaffin CL. hCG-induced down-regulation of PPAR $\gamma$ and liver $\mathrm{X}$ receptors promotes periovulatory progesterone synthesis by macaque granulosa cells. Endocrinology. 2010;151:5865-5872. doi: 10.1210/ en.2010-0698.

46. Fan $\mathrm{W}$, Yanase $\mathrm{T}$, Morinaga $\mathrm{H}$ et al. Activation of peroxisome proliferator-activated receptor-gamma and retinoid X receptor inhibits aromatase transcription via nuclear factor-kappaB. Endocrinology. 2005;146:85-92. doi: 10.1210/en.2004-1046.

47. Toda K, Okada T, Miyaura $\mathrm{C}$ et al. Fenofibrate, a ligand for PPAR alpha, inhibits aromatase cytochrome P450 expression 
in the ovary of mouse. J Lipid Res. 2003;44:265-270. doi: 10.1194/jlr.M200327-JLR200.

48. MacLaren LA, Guzeloglu A, Michel F et al. Peroxisome proliferator-activated receptor (PPAR) expression in cultured bovine endometrial cells and response to omega-3 fatty acid, growth hormone and agonist stimulation in relation to series 2 prostaglandin production. Domest Anim Endocrinol. 2006;30:155-169. doi: 10.1016/j.domaniend.2005.07.003.

49. Cammas L, Reinaud P, Bordas N et al. Developmental regulation of prostacyclin synthase and prostacyclin receptors in the ovine uterus and conceptus during the peri-implantation period. Reproduction. 2006;131:917-927. doi: 10.1530/rep.1.00799.

50. Nishimura K, Yamauchi N, Chowdhury VS et al. Expression of peroxisome proliferator-activated receptor isoforms in the rat uterus during early pregnancy. Cell Tissue Res. 2011;345:275-284. doi: 10.1007/s00441-011-1208-4.

51. Ulbrich SE, Schulke K, Groebner AE et al. Quantitative characterization of prostaglandins in the uterus of early pregnant cattle. Reproduction. 2009;138:371-382. doi: 10.1530/REP-09-0081.

52. Lord E, Murphy BD, Desmarais JA et al. Modulation of peroxisome proliferator-activated receptor delta and gamma transcripts in swine endometrial tissue during early gestation. Reproduction. 2006;131:929-942. doi: 10.1530/rep.1.00657.

53. Bogacka I, Bogacki M, Wasielak M. The effect of embryo presence on the expression of peroxisome proliferator activated receptor (PPAR) genes in the porcine reproductive system during periimplantation. Acta Vet Hung. 2013;61:405-415. doi: 10.1556/AVet.2013.013.

54. Klein C, Troedsson MH. Maternal recognition of pregnancy in the horse: a mystery still to be solved. Reprod Fertil. 2011;23:952-963. doi: 10.1071/RD10294.

55. Waclawik A. Novel insights into the mechanisms of pregnancy establishment: regulation of prostaglandin synthesis and signaling in the pig. Reproduction. 2011;142:389-399. doi: 10.1530/REP-11-0033.

56. Weems CW, Weems YS, Randel RD. Prostaglandins and reproduction in female farm animals. Vet J. 2006;171:206-228. doi: 10.1016/j.tvil.2004.11.014.

57. Kang HJ, Hwang SJ, Yoon JA et al. Activation of peroxisome proliferators-activated receptor $\delta(\mathrm{PPAR} \delta$ ) promotes blastocyst hatching in mice. Mol Hum Reprod. 2011;17:653-660. doi: $10.1093 / \mathrm{molehr} / \mathrm{gar} 030$.

58. Morawska-Pucinska E, Szymanska M1, Blitek A. Expression profile and role of prostacyclin receptor (PTGIR) in peri-implantation porcine conceptuses. Theriogenology. 2014;82:546-556. doi: 10.1016/j.theriogenology.2014.05.014.

59. Meade EA, McIntyre TM, Zimmerman GA et al. Peroxisome proliferators enhance cyclooxygenase-2 expression in epithelial cells. J Biol Chem. 1999;274:8328-8334. doi: 10.1074/ jbc.274.12.8328.

60. Sharma I, Dhawan V, Saha SC et al. In vitro effects of peroxisome proliferator-activated receptor- $\gamma$ ligands on gene expression in lipopolysaccharide-induced endometrial and endometriotic stromal cells. Fertil Steril. 2011;95:829-831. doi: $10.1016 /$ j.fertnstert.2010.09.008.

61. Sheldrick EL, Derecka K, Marshall E et al. Peroxisome-proliferator-activated receptors and the control of levels of prostaglandin-endoperoxide synthase 2 by arachidonic acid in the bovine uterus. Biochem J. 2007;406:175-183. doi: 10.1042 BJ20070089.

62. Ackerman WE, Zhang XL, Rovin BH et al. Modulation of cytokine-induced cyclooxygenase 2 expression by PPARG ligands through NFkappaB signal disruption in human WISH and amnion cells. Biol Reprod. 2005;73:527-535. doi: 10.1095/ biolreprod.104.039032.
63. Lim H, Gupta RA, Ma WG et al. Cyclo-oxygenase-2-derived prostacyclin mediates embryo implantation in the mouse via PPARdelta. Genes Dev. 1999;13:1561-1574. doi: $10.1101 /$ gad.13.12.1561.

64. Bogacka I, Bogacki M, Kurzyńska A et al. The involvement of peroxisome proliferator activated receptors (PPARs) in prostaglandin $\mathrm{F} 2 \alpha$ production by porcine endometrium. Reprod Biol. 2013;13:309-316. doi: 10.1016/j.repbio.2013. $\underline{10.001 .}$

65. Bogacka I, Bogacki M, Gaglewska M et al. In vitro effect of peroxisome proliferator activated receptor (PPAR) ligands on prostaglandin E2 synthesis and secretion by porcine endometrium during the estrous cycle and early pregnancy. J Physiol Pharmacol. 2013;64:47-54. PMID: 23568971.

66. Lim H, Dey SK. A novel pathway of prostacyclin signaling-hanging out with nuclear receptors. Endocrinology. 2002;143:3207-3210. doi: 10.1210/en.2002-220159.

67. Gillio-Meina C, Phang SH, Mather JP et al. Expression patterns and role of prostaglandin-endoperoxide synthases, prostaglandin E synthases, prostacyclin synthase, prostacyclin receptor, peroxisome proliferator-activated receptor delta and retinoid $\mathrm{x}$ receptor alpha in rat endometrium during artificially-induced decidualization. Reproduction. 2009;137:537-552. doi: 10.1530/REP-08-0294.

68. Okada H, Tsuzuki T, Shindoh H et al. Regulation of decidualization and angiogenesis in the human endometrium: mini review. J Obstet Gynaecol Res. 2014;40:1180-1187. doi: 10.1111/jog.12392.

69. Franczak A, Zmijewska A, Kurowicka B et al. Interleukin $1 \beta$ induces synthesis and secretion of prostaglandin $E_{2}$ in the porcine uterus during various periods of pregnancy and the estrous cycle. J Physiol Pharmacol. 2010;61:733-742. PMID: 21224505

70. Gunin AG, Bitter AD, Demakov AB et al. Effects of peroxisome proliferator activated receptors-alpha and -gamma agonists on estradiol-induced proliferation and hyperplasia formation in the mouse uterus. J Endocrinol. 2004;182:229-239. doi: 10.1677 /joe. 0.1820229 .

71. Keller H, Givel F, Perroud $\mathrm{M}$ et al. Signaling cross-talk between peroxisome proliferator-activated receptor/retinoid $\mathrm{X}$ receptor and estrogen receptor through estrogen response elements. Mol Endocrinol. 1995;9:794-804. doi: 10.1210/ me.9.7.794.

72. Makrigiannakis A, Minas V, Kalantaridou SN et al. Hormonal and cytokine regulation of early implantation. Trends Endocrinol Metab. 2006;17:178-185. doi: 10.1016/j.tem.2006.05.001.

73. Bogacki M, Wasielak M, Zięcik A. The role of cytokines and adhesion molecules in maternal recognition and establishment of pregnancy in pigs. J Anim Feed Sci. 2005;14:581-594.

74. Weiss G, Maseelall P, Schott LL et al. Adenomyosis a variant, not a disease? Evidence from hysterectomized menopausal women in the Study of Women's Health Across the Nation (SWAN). Fertil Steril. 2009;91:201-216. doi: 10.1016/j.fertnstert.2007.11.025.

75. Szymanowski K, Niepsuj-Biniaś J, Dera-Szymanowska A et al. An influence of immunomodulation on Th1 and Th2 immune response in endometriosis in an animal model. Biomed Res Int. 2013;2013:849492. doi: 10.1155/2013/849492.

76. Minge CE, Robker RL, Norman RJ. PPAR gamma: coordinating metabolic and immune contributions to female fertility. PPAR Res. 2008;2008:243791. doi: 10.1155/2008/243791.

77. Wanichkul T, Han S, Huang RP et al. Cytokine regulation by peroxisome proliferator-activated receptor gamma in human endometrial cells. Fertil Steril. 2003;79:763-769. doi: $\underline{10.1016 /}$ S0015-0282(02)04835-5. 
78. McKinnon B, Bersinger NA, Mueller MD. Peroxisome proliferating activating receptor gamma-independent attenuation of interleukin 6 and interleukin 8 secretion from primary endometrial stromal cells by thiazolidinediones. Fertil Steril. 2012;97:657-664. doi: 10.1016/j.fertnstert.2011.12.001.

79. Bogacka I, Bogacki M, Boruszewska D et al. Expression of peroxisome proliferator activated receptor (PPAR) genes in porcine endometrium exposed in vitro to IL-6 and INFy. Reprod Biol. 2012;12:157-170. doi: 10.1016/S1642431X(12)60083-7.

80. Jiang C, Ting AT, Seed B. PPAR-gamma agonists inhibit production of monocyte inflammatory cytokines. Nature. 1998;391:82-86. doi: 10.1038/34184.

81. Schaiff WT, Bildirici I, Cheong M et al. Peroxisome proliferator-activated receptor-gamma and retinoid $\mathrm{X}$ receptor signaling regulate fatty acid uptake by primary human placental trophoblasts. J Clin Endocrinol Metab. 2005;90:4267-4275. doi: 10.1210/jc.2004-2265.

82. Fournier T, Tsatsaris V, Handschuh $\mathrm{K}$ et al. PPARs and the placenta.Placenta. 2007;28:65-76. doi:10.1016/j.placenta.2006.04.009.

83. Fournier T, Guibourdenche J, Handschuh $\mathrm{K}$ et al. PPAR and human trophoblast differentiation. J Reprod Immunol. 2011;90:41-49. doi: 10.1016/j.jri.2011.05.003.

84. Capparuccia L, Marzioni D, Giordano A et al. PPARgamma expression in normal human placenta, hydatidiform mole and choriocarcinoma. Mol Hum Reprod. 2002;8:574-579. doi: 10.1093/molehr/8.6.574.

85. Asami-Miyagishi R, Iseki S, Usui M et al. Expression and function of PPARgamma in rat placental development. Biochem Biophys Res Commun. 2004;315:497-501. doi: 10.1016/j. bbrc.2004.01.074.

86. Degrelle SA, Murthi P, Evain-Brion D et al. Expression and localization of DLX3, PPARG and SP1 in bovine trophoblast during binucleated cell differentiation. Placenta. 2011;32:917 -920. doi: 10.1016/j.placenta.2011.08.014.

87. Wang Q, Fujii H, Knipp GT. Expression of PPAR and RXR isoforms in the developing rat and human term placentas. Placenta. 2002;23:661-671. doi: 10.1053/plac.2002.0855.

88. Holdsworth-Carson SJ, Permezel M, Riley C et al. Peroxisome proliferator-activated receptors and retinoid $\mathrm{X}$ receptor-alpha in term human gestational tissues: tissue specific and labour-associated changes. Placenta. 2009;30:176-186. doi: 10.1016/j.placenta.2008.11.013.

89. Kubota N, Terauchi Y, Miki H et al. PPAR gamma mediates high-fat diet-induced adipocyte hypertrophy and insulin resistance. Mol Cell. 1999;4:597-609. doi: 10.1016/S10972765(00)80210-5.

90. Nadra K, Quignodon L, Sardella C et al. PPAR gamma in placental angiogenesis. Endocrinology. 2010;151:4969-4981. doi: 10.1210/en.2010-0131.

91. Zhu Y, Kan L, Qi C et al. Isolation and characterization of peroxisome proliferator-activated receptor (PPAR) interacting protein (PRIP) as a coactivator for PPAR. J Biol Chem. 2000;275:13510-13516. doi: 10.1074/jbc.275.18.13510.

92. Shalom-Barak T, Nicholas JM, Wang Y et al. Peroxisome proliferator-activated receptor gamma controls Muc1 transcription in trophoblasts. Mol Cell Biol. 2004;24:10661-10669. doi: 10.1128/MCB.24.24.10661-10669.2004.

93. Tarrade A, Schoonjans K, Guibourdenche J et al. PPAR gamma/RXR alpha heterodimers are involved in human CG beta synthesis and human trophoblast differentiation. Endocrinology. 2001;142:4504-4514. doi: 10.1210/endo.142. 10.8448 .

94. Schaiff WT, Carlson MG, Smith SD et al. Peroxisome proliferator-activated receptor-gamma modulates differentiation of human trophoblast in a ligand-specific manner. J Clin Endocrinol Metab. 2000;85:3874-3881. doi: 10.1210/jc.85.10.3874.

95. Tarrade A, Schoonjans K, Pavan Let al. PPAR gamma/RXR alpha heterodimers control human trophoblast invasion. J Clin Endocrinol Metab. 2001;86:5017-5024. doi: 10.1210/ jcem.86.10.7924.

96. Fournier T, Thérond P, Handschuh K et al. PPARgamma and early human placental development. Curr Med Chem. 2008;15:3011-3024. doi: 10.2174/092986708786848677.

97. Bilban M, Haslinger P, Prast J et al. Identification of novel trophoblast invasion-related genes: heme oxygenase- 1 controls motility via peroxisome proliferator-activated receptor gamma. Endocrinology. 2009;150:1000-1013. doi: 10.1210/en.20080456.

98. Handschuh K, Guibourdenche J, Guesnon M et al. Modulation of PAPP-A expression by PPAR gamma in human first trimester trophoblast. Placenta. 2006;27:127-134. doi: 10.1016/j.placenta.2005.10.012.

99. Handschuh K, Guibourdenche J, Tsatsaris V et al. Human chorionic gonadotropin produced by the invasive trophoblast but not the villous trophoblast promotes cell invasion and is down-regulated by peroxisome proliferator-activated receptor-gamma. Endocrinology. 2007;148:5011-5019. doi: 10.1210/en.2007-0286.

100. Hutter S, Knabl J, Andergassen U et al. The Role of PPARs in placental immunology: A systematic review of the literature.PPAR Res. 2013;2013:970276. doi: 10.1155/2013/970276.

101. Lappas M, Permezel M, Rice GE. Leptin and adiponectin stimulate the release of proinflammatory cytokines and prostaglandins from human placenta and maternal adipose tissue via nuclear factor-kappaB, peroxisomal proliferator-activated receptor-gamma and extracellularly regulated kinase $1 / 2$. Endocrinology. 2005;146:3334-3342. doi: 10.1210/en.20050406.

102. Keelan JA, Blumenstein M, Helliwell RJ et al. Cytokines, prostaglandins and parturition - a review. Placenta. 2003;24(Suppl A):33-46. doi: 10.1053/plac.2002.0948.

103. Duttaroy AK. Transport of fatty acids across the human placenta: a review. Prog Lipid Res. 2009;48:52-61. doi: 10.1016/j. plipres.2008.11.001.

104. Zhang S, Regnault TR, Barker PL et al. Placental adaptations in growth restriction. Nutrients. 2015;7:360-389. doi: 10.3390/ nu7010360.

105. Xu Y, Wang Q, Cook TJ et al. Effect of placental fatty acid metabolism and regulation by peroxisome proliferator activated receptor on pregnancy and fetal outcomes.J Pharm Sci. 2007;96:2582-2606. doi: 10.1002/jps.20973.

106. Bildirici I, Roh CR, Schaiff WT et al. The lipid droplet-associated protein adipophilin is expressed in human trophoblasts and is regulated by peroxisomal proliferator-activated receptor-gamma/retinoid X receptor.J Clin Endocrinol Metab. 2003;88:6056-6062. doi: 10.1210/jc.2003-030628

107. Nadra K, Anghel SI, Joye E et al. Differentiation of trophoblast giant cells and their metabolic functions are dependent on peroxisome proliferator-activated receptor beta/delta. $\mathrm{Mol}$ Cell Biol. 2006;26:3266-3281. doi: 10.1128/MCB.26.8.32663281.2006.

108. Pakrasi PL, Jain AK. Cyclooxygenase-2 derived PGE2 and PGI2 play an important role via EP2 and PPAR delta receptors in early steps of oil induced decidualization in mice. Placenta. 2008;29:523-530. doi: 10.1016/j.placenta.2008. 03.001.

109. Mohan M, Malayer JR, Geisert RD et al. Expression patterns of retinoid $\mathrm{X}$ receptors, retinaldehyde dehydrogenase, and peroxisome proliferator activated receptor gamma in bovine 
preattachment embryos. Biol Reprod. 2002;66:692-700. doi: 10.1095/biolreprod66.3.692.

110. Rees WD, McNeil CJ, Maloney CA. The roles of PPARs in the fetal origins of metabolic health and disease. PPAR Res. 2008;2008:459030. doi: 10.1155/2008/459030.

111. Lindegaard ML, Nielsen LB. Maternal diabetes causes coordinated down-regulation of genes involved with lipid metabolism in the murine fetal heart. Metabolism. 2008;57:766-773. doi: 10.1016/j.metabol.2008.01.016.

112. Martínez N, White V, Kurtz M et al. Activation of the nuclear receptor PPAR $\alpha$ regulates lipid metabolism in foetal liver from diabetic rats: implications in diabetes-induced foetal overgrowth. Diabetes Metab Res Rev. 2011;27:35-46. doi: 10.1002/dmrr.1151.

113. Park KS, Lee RD, Kang SK et al. Neuronal differentiation of embryonic midbrain cells by upregulation of peroxisome proliferator-activated receptor-gamma via the JNK-dependent pathway. Exp Cell Res. 2004;297:424-433. doi: 10.1016/j. yexcr.2004.03.034.

114. Malm T, Mariani M, Donovan LJ et al. Activation of the nuclear receptor $\mathrm{PPAR} \beta$ is neuroprotective in a transgenic mouse model of Alzheimer's disease through inhibition of inflammation. J Neuroinflammation. 2015;12:7. doi: 10.1186/s12974-0140229-9.

Submitted: 2 February, 2015 Accepted after reviews: 4 September, 2015 Available as AoP: 4 September, 2015 